\title{
TANGGUNG JAWAB NOTARIS ATAS AKTA AUTENTIK YANG \\ DIBUATNYA DENGAN SURAT KUASA YANG CACAT HUKUM SERTA TIDAK DIBACAKANNYA AKTA TERSEBUT (STUDI KASUS PUTUSAN NOMOR 25/PDT.G/2017/PN.CBI)
}

\author{
Eric Sandro \\ (Mahasiswa Program S1 Fakultas Hukum Universitas Tarumanagara) \\ (Email: eric.205160177@stu.untar.ac.id)
}

\section{Dr. Tjempaka S.H., M.H., M.Kn. \\ (Corresponding Author)}

( Dosen Fakultas Hukum Universitas Tarumanagara, Meraih Sarjana Hukum pada Fakultas Hukum Universitas Tulang Bawang Lampung, Magister Hukum pada Fakultas Hukum Universitas Lampung, Magister Kenotariatan pada Fakultas Hukum Universitas Diponegoro, Doktor Hukum pada Fakultas Hukum Universitas Trisakti)

(Email: not.tjempaka@gmail.com)

\begin{abstract}
At this time the need for Notary services is increasing, especially related to legal actions that are Private Law. Legal actions carried out by the parties concerned are usually set forth in an agreement made by the parties themselves and to be more binding on these legal actions the parties usually make an agreement in an authentic deed made by the competent official, the Notary. In exercising his office, a Notary shall also have the obligation to act in a trustworthy, honest, fair, independent, non-partisan manner and to safeguard the interests of the parties involved in a legal action. A Notary when carrying out his position is obligated to make certain that what is written in a notary deed is understood by the parties and the notary deed is written accordance to the parties's desire. A Notary must always be responsible for any mistakes that was made by the Notary especially if the mistakes caused a material loss to its clients.
\end{abstract}

Keywords: Notary Responsibility, Letter of Authority, Authentic Deed

\section{Pendahuluan}

\section{A. Latar Belakang}

Pada zaman yang berkembang dengan pesat ini jasa Notaris kian hari kian diperlukan oleh masyrakat, terutama dengan kebutuhan masyarakat dalam melakukan perbuatan hukum yang bersifat Hukum Perdata. Perbuatan hukum yang dilakukan oleh para pihak yang berkepentingan biasanya dituangkan dalam suatu perjanjian yang dilakukan oleh para pihak itu sendiri dan untuk 
Eric Sandro \& Tjempaka

EFEKTIVITAS MENGENAI KEPASTIAN HUKUM PENERAPAN DELIK FORMIL DALAM PASAL 2 AYAT (1) JUNCTO PASAL 3

\section{Jurnal Huknem Adigamâ}

Volume 2 Nomor 2, Desember 2019 E-ISSN: 2655-7347 UNDANG-UNDANG NOMOR 20 TAHUN 2001 TENTANG PERUBAHAN ATAS UNDANG-UNDANG NOMOR 31 TAHUN 1999 TENTANG PEMBERANTASAN TINDAK PIDANA KORUPSI (STUDI PUTUSAN MAHKAMAH KONSTITUSI REPUBLIK INDONESIA NOMOR 25/PUU-XIV/2016)

lebih mengikat perbuatan hukum tersebut biasanya para pihak membuat suatu perjanjian dalam akta autentik yang dibuat oleh pejabat yang berwenang yaitu Notaris. ${ }^{1)}$

Menurut Pasal 1 angka 1 Undang-Undang Nomor 2 tahun 2014 tentang Perubahan atas Undang-Undang Nomor 30 tahun 2004 tentang Jabatan Notaris disebutkan bahwa yang disebut Notaris adalah pejabat umum yang berwenang membuat akta autentik dan kewenangan lainnya sebagaimana dimaksud dalam undang-undang ini atau berdasarkan undang-undang lainnya.

Notaris dalam melaksanakan tugasnya sebagai seorang pejabat umum berwenang untuk membuat suatu akta autentik yang berisikan semua perjanjian, perbuatan dan penetapan-penetapan yang dibuat oleh para penghadap dihadapan seorang Notaris dalam bentuk yang telah ditetapkan dalam peraturan perundang-undangan. Seorang Notaris juga memiliki tugas untuk menjamin tanggal pembuatan suatu akta autentik, menyimpan akta autentik yang dibuat olehnya, memberikan grosse, kutipan dan salinan akta autentik yang dibuatnya.

Menurut Pasal 1868 KUHPerdata suatu akta autentik ialah suatu akta yang dibuat dalam bentuk yang ditentukan undang-undang oleh atau dihadapan pejabat umum yang berwenang untuk itu di tempat akta itu dibuat. Dan pasal ini merupakan dasar dari penyebutan notaris sebagai seorang pejabat umum.

Dalam menjalankan tugas dan jabatannya seorang Notaris harus selalu bertindak sesuai amanah, tidak berpihak, saksama, jujur, saksama, teliti, berhati-hati dan juga menjaga kepentingan pihak-pihak yang terkait dalam sebuah perbuatan hukum

Jika seorang Notaris dalam pembuatan aktanya tidak sesuai dengan bentuk yang telah ditetapkan dalam UUJN, maka Notaris tersebut dapat dikenai sanksi yang telah diatur di dalam UUJN dan Kode Etik Notaris yang dimana menurut

1) Putra Arafaid, "Tanggung Jawab Hukum Notaris Terhadap Akta In Originali”, Jurnal IUS Kajian Hukum dan Keadlian, Vol.5, No.3 Tahun 2017, hal.511 
Eric Sandro \& Tjempaka

EFEKTIVITAS MENGENAI KEPASTIAN HUKUM PENERAPAN DELIK FORMIL DALAM PASAL 2 AYAT (1) JUNCTO PASAL 3

\section{Jurnal Huknem Adigamä}

Volume 2 Nomor 2, Desember 2019 E-ISSN: 2655-7347 UNDANG-UNDANG NOMOR 20 TAHUN 2001 TENTANG PERUBAHAN ATAS UNDANG-UNDANG NOMOR 31 TAHUN 1999 TENTANG PEMBERANTASAN TINDAK PIDANA KORUPSI (STUDI PUTUSAN MAHKAMAH KONSTITUSI REPUBLIK INDONESIA NOMOR 25/PUU-XIV/2016)

Pasal 6 Kode Etik Notaris, Sanksi yang dapat dikenakan terhadap anggota yang melakukan pelanggaran kode etik dapat berupa :

a. Teguran;

b. Peringatan;

c. Pemberhentian sementara dari keanggotaan Perkumpulan;

d. Pemberhentian dengan hormat dari keanggotaan Perkumpulan;

e. Pemberhentian dengan tidak hormat dari keanggotaan Perkumpulan.

Dalam pembuatan akta autentik, para pihak dapat memberikan kuasanya terhadap orang lain apabila dirasakan ada kesibukan lain yang lebih penting. Surat kuasa merupakan suatu dokumen yang sangat sering digunakan di dalam masyarakat untuk keperluan-keperluan. Pada awalnya penggunaan surat kuasa ini hanya lazim digunakan pada orang-orang yang memiliki pekerjaan yang berhubungan dengan hokum, namun sekarang surat kuasa sangat sering digunakan oleh masyarakat bahkan untuk hal-hal kecil pun.

Pemberian kuasa adalah suatu persetujuan seseorang sebagai pemberi kuasa dengan orang lain sebagai penerima kuasa, guna melakukan suatu perbuatan/tindakan untuk dapat "atas nama" si pemberi kuasa. ${ }^{2}$

Perjanjian untuk memberikan kuasa kepada orang lain (lastgeving) sudah mulai ada pada zaman-zaman pertengahan, yang disebut dengan istilah mandatum oleh bangsa romawi. Manus memiliki pengertian tangan dan datum berarti memberikan tangan. Pada zaman abad pertengahan pemberian kuasa ini hanya diberikan sesama teman dan diberikan tanpa memberikan upah, walaupun pada biasanya setelah penerima kuasa telah membantu pemberi kuasa untuk melakukan sesuatu untuk dan atas nama pemberi kuasa tersebut, penerima kuasa akan diberikan bayaran yang bukan merupakan upah, namun berupa uang penghargaan yang diberikan oleh pemberi kuasa tersebut. ${ }^{3)}$ Kuasa adalah sebuah kewenangan seseorang untuk melakukan sebuah tindakan hukum

2) Yahya Harahap, Segi-Segi Hukum Perjanjian, (Bandung: Alumni, 1986), hal. 306.

3) Herlien Budiono, Perwakilan, Kuasa dan Pemberian Kuasa, Majalah Renvoi, Nomor 6.42.IV, 3 November 2006, Hal. 68. 
Eric Sandro \& Tjempaka

EFEKTIVITAS MENGENAI KEPASTIAN HUKUM PENERAPAN DELIK FORMIL DALAM PASAL 2 AYAT (1) JUNCTO PASAL 3

untuk kepentingan pemberi kuasa dan atas nama pemberi kuasa tersebut. Dalam arti bahwa kewajiban untuk melaksanakan prestasi hanya terdapat pada satu pihak saja, yaitu penerima kuasa. ${ }^{4)}$

Notaris sebagai pejabat haruslah dapat memberikan perlindungan hukum kepada masyarakat dalam pembuatan akta autentik, Notaris dalam membuat sebuah akta autentik wajib memuat kehendak dari para penghadap dan akta tersebut harus dipahami oleh para penghadapnya. Notaris memiliki kewajiban untuk membacakan isi akta autentik yang dibuatnya agar para penghadap memahami dan mengetahui dengan jelas isi akta dan segala informasi terkait akta tersebut. Hal ini dilakukan agar tidak menimbulkan kesalahpahaman mengenai isi akta tersebut.

Dalam melaksanakan jabatannya, tugas dan kewajiban Notaris tersebut telah di atur di dalam UUJN. Pelaksanaan kewajiban Notaris dalam pembuatan akta autentik dalam jabatannya ditentukan dalam Pasal 16 UUJN-P yang dimana mengatur mengenai pembacaan sebuah akta autentik yang dibuat oleh Notaris merupakan kewajiban Notaris, pembacaan akta autentik tersebut haruslah dilakukan dihadapan para penghadap dan harus dihadiri oleh 2 (dua) orang saksi. Apabila dalam pembuatan akta autentik Notaris tidak membacakan akta tersebut maka menurut Pasal 16 ayat (9) UUJN-P, akta autentik tersebut mengalami degradasi menjadi akta di bawah tangan dan tidak memiliki kekuatan hukum sebagai akta autentik.

Pada prakteknya dalam pembuatan suatu akta bisa mengalami beberapa kendala, seperti kasus yang terjadi dalam Putusan Pengadilan Negeri Cibinong Nomor 25/Pdt.G/2017/PN.Cbi yang di mana kronologi kasusnya adalah terdapat sebuah perjanjian Sewa-Menyewa antara Penggugat atas nama Juju Andriyani yang merupakan pemilik sebuah ruko Pemilik Bangunan Rumah Toko (Ruko) Ukuran 187 m2, yang berdiri diatas Tanah Hak Milik seluas 2.230

\footnotetext{
4) Ibid., hal.68.
} 
Eric Sandro \& Tjempaka

EFEKTIVITAS MENGENAI KEPASTIAN HUKUM PENERAPAN DELIK FORMIL DALAM PASAL 2 AYAT (1) JUNCTO PASAL 3 UNDANG-UNDANG NOMOR 20 TAHUN 2001 TENTANG PERUBAHAN ATAS UNDANG-UNDANG NOMOR 31 TAHUN 1999 TENTANG PEMBERANTASAN TINDAK PIDANA KORUPSI (STUDI PUTUSAN MAHKAMAH KONSTITUSI REPUBLIK INDONESIA

Volume 2 Nomor 2, Desember 2019 E-ISSN: 2655-7347

m2 sebagaimana tercatat dalam Sertipikat Hak Milik No. 97, Cileungsi, Bogor atas nama Juju Andryani, dikenal dan terletak di Jalan Camat Enjan No. 18 A, Rt.002 RW.016 Kelurahan Cileungsi, Kecamatan Cileungsi Kabupaten Bogor, dengan PT. Indomarco Prismatama, selaku Tergugat I melalui Notaris Umang Retno Ayu Melasari, S.H., selaku Tergugat II.

Bahwa kemudian pada tanggal 29 September 2016 Penggugat diundang oleh Para Tergugat untuk menandatangani Akta Sewa Menyewa dan menerima uang pembayaran dari perjanjian Sewa Menyewa tersebut. Namun dalam penandatangan Akta Sewa-Menyewa ternyata Surat Kuasa dari Tergugat I belum ada, sehingga menyebabkan pihak yang mewakilkan Tergugat I dalam penandatangan Akta Sewa Menyewa tersebut tidak memiliki kewenangan.

Namun demikian, Penggugat tetap diminta untuk menandatangani Akta Sewa Menyewa tersebut dan Penggugat juga tidak diberikan kelengkapan dokumen yang seharusnya diberikan. Kemudian Tergugat I juga melakukan pemunduran tanggal pada Surat Kuasa yang seharusnya diberikan pada tanggal 29 September 2016 oleh Tergugat II. Padahal menurut Pasal 47 ayat(1) UUJN menyatakan bahwa surat kuasa autentik atau surat lainya yang menjadi dasar kewenangan seorang penghadap dalam menandatangani Akta yang di keluarkan secara original atau surat kuasa yang bersifat di bawah tangan wajib dilekatkan pada Minuta Akta. ${ }^{5)}$

Pada saat penandatanganan akta tersebut, Tergugat II juga tidak membacakan isi akta kepada Penggugat padahal pembacaan akta haruslah dilakukan oleh seorang Notaris karena merupakan kewajibannya yang sebagaimana telah diatur di dalam UUJN. Tergugat II pada saat penandatanganan akta tersebut jelas memihak kepada Tergugat I karena walaupun surat kuasa tidak ada dan perwakilan dari Tergugat I tidak hadir pada

\footnotetext{
5) Crystal Yoanna, Winanto Wiryomartani, dan Widodo Suryandono, "Pembuatan Akta Sewa Menyewa Atas Dasar Surat Kuasa Dan Renvoi Yang Cacat Hukum”. Notary UI. Vol.1 No.002 Tahun 2019, hal.10.
} 
Eric Sandro \& Tjempaka

EFEKTIVITAS MENGENAI KEPASTIAN HUKUM PENERAPAN DELIK FORMIL DALAM PASAL 2 AYAT (1) JUNCTO PASAL 3

\section{Jurnal Huknem Adigamâ}

Volume 2 Nomor 2, Desember 2019 E-ISSN: 2655-7347 UNDANG-UNDANG NOMOR 20 TAHUN 2001 TENTANG PERUBAHAN ATAS UNDANG-UNDANG NOMOR 31 TAHUN 1999 TENTANG PEMBERANTASAN TINDAK PIDANA KORUPSI (STUDI PUTUSAN MAHKAMAH KONSTITUSI REPUBLIK INDONESIA NOMOR 25/PUU-XIV/2016)

saat penandatanganan akta tersebut Tergugat II teteap meminta Penggugat untuk menandatangani dan tidak juga membacakan isi dari akta tersebut sehingga terkesan Tergugat II ingin Penggugat untuk segera menandatangani akta tersebut.

Kemudian berdasarkan keterangan dari Tergugat II perihal Surat Kuasa belum turun, Penggugat tidak mempercayai jika Akta Sewa Menyewa tersebut ditandatangani oleh Muhammad Agus Noviyanto selaku penerima kuasa Tergugat I pada tanggal 29 September, karena hal ini sangat tidak masuk akal, mengingat surat kuasa dari Tergugat II baru turun pada tanggal 27 Oktober. Selain itu Penggugat juga tidak pernah melihat wujud maupun identitas dari Muhammad Agus Noviyanto selaku penerima kuasa dari Tergugat I.

Kemudian Penggugat juga baru menerima penyerahan Akta Sewa Menyewa Nomor 31 pada tanggal 28 Oktober 2016 dari tim lapangan Tergugat I dan Penggugat hanya melihat sepintas isi akta dan langsung menandatangani tanda terima.

Penggugat kemudian menggugat ke pengadilan yang di mana penggugat menuntut bahwa Akta Sewa Menyewa tersebut dibatalkan namun Hakim pada Pengadilan Negeri Cibinong dalam menjatuhkan putusannya tidak membatalkan Akta Sewa Menyewa tersebut. Pengadilan Negeri Cibinong juga tidak menimbang bagaimana pertanggung jawaban Notaris dalam putusan tersebut.

\section{B. Perumusan Masalah}

Pada penelitian ini membahas mengenai permasahan:

1. Bagaimanakah tanggung jawab seorang notaris terhadap akta autentik yang dibuatnya dengan surat kuasa yang cacat hukum ?

2. Bagaimanakah tanggung jawab seorang notaris terhadap akta autentik yang dibuatnya yang tidak di bacakan di hadapan para pihak? 
Eric Sandro \& Tjempaka

EFEKTIVITAS MENGENAI KEPASTIAN HUKUM PENERAPAN DELIK FORMIL DALAM PASAL 2 AYAT (1) JUNCTO PASAL 3

\section{Jurnal Huknem Adigamâ}

Volume 2 Nomor 2, Desember 2019 E-ISSN: 2655-7347 UNDANG-UNDANG NOMOR 20 TAHUN 2001 TENTANG PERUBAHAN ATAS UNDANG-UNDANG NOMOR 31 TAHUN 1999 TENTANG PEMBERANTASAN TINDAK PIDANA KORUPSI (STUDI PUTUSAN MAHKAMAH KONSTITUSI REPUBLIK INDONESIA NOMOR 25/PUU-XIV/2016)

Dengan melihat pada permasalahan yang dibahas, sehingga penulisan ini bertujuan untuk:

1. Untuk mengetahui pertanggungjawaban seorang notaris terhadap akta autentik yang dibuatnya dengan surat kuasa yang cacat hukum.

2. Untuk mengetahui pertanggungjawaban seorang notaris terhadap akta autentik yang dibuatnya yang tidak di bacakan.

\section{Metode Penelitian}

Metode adalah suatu unsur mutlak yang wajib ada di dalam suatu penetilitian yang memiliki fungsi untuk mengembangkan ilmu pengetahuan. Untuk mengetahui permasalahan apa yang di hadapi dan supaya penulis dapat melakukan evaluasi dari masalah yang telah dijelaskan diatas, sehingga dalam mengumpulkan fakta-fakta, bahan-bahan, dan data yang diperlukan, maka penulis menggunakan metode yaitu sebagai berikut:

1. Jenis Penelitian

Jenis penelitian yang akan digunakan dalam penelitian ini adalah yuridis normatif, karena penelitian ini dilakukan berdasarkan metode dan sebuah pemikiran tertentu untuk mempelajari suatu data yang relevan, terkait dan akurat dengan permasalahan yang akan diteliti dalam artikel ini maka penulis menggunakan metodelogi penelitian yuridis normatif dengan penggunaan studi kepustakaan dengan menggunakan bahan-bahan kepustakaan.

2. Jenis dan Sumber Data

Jenis penelitian yang akan digunakan dalam penelitian ini adalah penelitian hukum normatif. Sumber data yang digunakan antara lain:

1) Bahan hukum primer adalah segala aturan hukum yang penegakannya atau pemaksaannya dilakukan oleh negara. ${ }^{6)}$ Bahan hukum primer

6) I Made. Pasek Diantha, Metodologi Penelitian. Hukum Normatif. Dalam Justifikasi. Teori Hukum,(Jakarta: PT Fajar Interpratama Mandiri, 2017), hal.143. 
Eric Sandro \& Tjempaka

EFEKTIVITAS MENGENAI KEPASTIAN HUKUM PENERAPAN DELIK FORMIL DALAM PASAL 2 AYAT (1) JUNCTO PASAL 3

Jurnal Huknem Adigamâ

Volume 2 Nomor 2, Desember 2019 E-ISSN: 2655-7347
UNDANG-UNDANG NOMOR 20 TAHUN 2001 TENTANG PERUBAHAN ATAS UNDANG-UNDANG NOMOR 31 TAHUN 1999 TENTANG PEMBERANTASAN TINDAK PIDANA KORUPSI (STUDI PUTUSAN MAHKAMAH KONSTITUSI REPUBLIK INDONESIA

NOMOR 25/PUU-XIV/2016)

terdiri dari perundang-undangan, catatan-catatan resmi atau risalah dalam pembuatan undang-undang dan putusan-putusan hakim, yaitu :

a. UUD 1945

b. Kitab Undang-Undang Hukum Perdata;

c. Undang-Undang Nomor 2 Tahun 2014 Tentang Jabatan Notaris;

d. Kode Etik Notaris.

2) Bahan Hukum Sekunder merupakan sumber hukum yang didapatkan dari sebuah publikasi hukum, dokumen-dokumen resmi atau yang meliputi: buk-buku hukum, majalah hukum, jurnal hukum, ataupun sebuah putusan pengadilan (Dalam hal ini Putusan Pengadilan Negeri Cibinong Nomor 25/Pdt.g/2017/Pn Cbi);

3) Bahan Hukum Tersier adalah bahan-bahan hukum yang dapat memberikan arahan, penunjang ataupun penjelasan terhadap data hukum primer dan data hukum sekunder, contohnya kamus, ensiklopedia, indeks kualitatif dan seterusnya.

3. Teknik Pengumpulan Data

Dalam pengumpulan data peneilitian ini, penulis akan menggunakan cara pengumpulan data dengan studi pustaka terhadap bahan-bahan hukum primer, bahan-bahan hukum sekunder dan bahan-bahan nonhukum, serta dengan melakukan wawancara. Adapun pengumpulan data melalui wawancara dilakukan dengan mewawancarai beberapa pakar maupun narasumber untuk mendapatkan bahan hukum primer yang berkaitan dengan penelitian yang dilakukan.

4. Teknik Analisis Data

Data-data yang telah dikumpulkan kemudian akan dilakukan pengolahan, dan hasil pengolahan data tersebut akan dianalisis dengan teori yang didapatkan. Teknik analisis data yang digunakan di dalam penelitian ini adalah penelitian hukum yang bersifat preskriptif. Dalam penelitian preskriptif ini, penulis akan memberikan argumentasi terhadap hasil-hasil yang telah diperoleh melalui sumber-sumber penelitian. Dalam 
Eric Sandro \& Tjempaka

EFEKTIVITAS MENGENAI KEPASTIAN HUKUM PENERAPAN DELIK FORMIL DALAM PASAL 2 AYAT (1) JUNCTO PASAL 3

\section{Jurnal Huknem Adigamâ}

Volume 2 Nomor 2, Desember 2019 E-ISSN: 2655-7347 UNDANG-UNDANG NOMOR 20 TAHUN 2001 TENTANG PERUBAHAN ATAS UNDANG-UNDANG NOMOR 31 TAHUN 1999 TENTANG PEMBERANTASAN TINDAK PIDANA KORUPSI (STUDI PUTUSAN MAHKAMAH KONSTITUSI REPUBLIK INDONESIA NOMOR 25/PUU-XIV/2016)

menganalisis data dalam penelitian ini, kemudian penulis menggunakan 1 (satu) pendekatan yaitu pendekatan perundang-undangan (Statute Approach).

\section{Pembahasan}

\section{A. Tanggung Jawab Notaris}

Notaris sebagai seorang pejabat umum (openbaar ambtenaari) yang memiliki kewenangan untuk membuat sebuah akta autentik tentu saja memiliki tanggung jawab atas akta autentik yang dibuatnya tersebut. Hal ini dikarenakan akta autentik yang dibuat olehnya mempunyai akibat-akibat hukum. Tanggung jawab seorang Notaris menurut Nico terbagi menjadi empat, yaitu:

1. Tanggung jawab Notaris terhadap akta yang dibuatnya secara perdata;

2. Tanggung jawab Notaris terhadap akta yang dibuatnya secara pidama;

3. Tanggung jawab Notaris terhadap akta yang dibuatnya berdasarkan Peraturan Jabatan Notaris;

4. Tanggung jawab Notaris terhadap Kode Etik Notaris dalam menjalankan tugas dan jabatannya sebagai pejabat umum. ${ }^{7)}$

Tanggung jawab seorang Notaris terhadap akta autentik yang dibuatnya yang berhubungan secara langsung dengan jabatannya sebagai seorang pejabat umum akan dijelaskan dibawah ini:

\section{Tanggung jawab Notaris secara perdata atas akta yang dibuatnya.}

Tanggung jawab seorang Notaris dalam bidang perdata terjadi apabila dalam pembuatan sebuah akta autentik seorang Notaris dalam kapasitasnya sebagai seorang pejabat umum melakukan perbuatan melawan hukum. Tanggung jawab secara perdata karena perbuatan melawan hokum ini mencakup segala kesalahan yang dilakukan oleh Notaris yang mengakibatkan kerugian kepada pihak-pihak lainnya ketika menjalankan tugas dan jabatannya sebagai seorang pejabat umum.

\footnotetext{
7) Abdul Ghofur Anshori, Lembaga Kenotariatan Indonesia, (Yogyakarta: UII Press, 2009), hal. 34.
} 
Eric Sandro \& Tjempaka

EFEKTIVITAS MENGENAI KEPASTIAN HUKUM PENERAPAN DELIK FORMIL DALAM PASAL 2 AYAT (1) JUNCTO PASAL 3

\section{Jurnal Huknem Adigamâ}

Volume 2 Nomor 2, Desember 2019 E-ISSN: 2655-7347
NG NOMOR 20 TAHUN 2001 TENTANG PERUBAHAN ATAS UNDANG-UNDANG NOMOR 31 TAHUN 1999 TENTANG PEMBERANTASAN TINDAK PIDANA KORUPSI (STUDI PUTUSAN MAHKAMAH KONSTITUSI REPUBLIK INDONESIA NOMOR 25/PUU-XIV/2016)

\section{Tanggung jawab Notaris secara pidana atas akta yang dibuatnya.}

Tanggung jawab secara pidana seorang Notaris ini tidak tidak diatur secara langsung di dalam UUJN, namun hal ini tidak berarti seorang Notaris dalam melaksanakan jabatannya tidak dapat dituntut untuk bertangung jawab secara pidana, seorang Notaris yang melakukan tindak pidana pada saat menjalankan tugasnya sebagai seorang pejabat umum dan telah memenuhi unsur-unsur sebuah perbuatan pidana maka Notaris tersebut dapat dituntut untuk bertanggung jawab secara pidana. Tindak pidana yang dapat dilakukan oleh Notaris ini telah diatur didalam Pasal 264 KUHPidana mengenai pemalsuan surat yang dilakukan terhadap akta autentik.

\section{Tanggung jawab Notaris berdasarkan peraturan jabatan Notaris (UUJN)}

Tanggung jawab seorang Notaris terhadap UUJN ini diatur di dalam Pasal 84 dan Pasal 85 UUJN yang menyatakan apabila seorang Notaris melakukan pelanggaran-pelanggaran terhadap larangan yang tercantum di dalam UUJN yang mengakibatkan sebuah akta autentik yang dibuat olehnya mengalami degradasi menjadi akta dibawah tangan ataupun sebuah akta autentik yang dibuatnya menjadi batal demi hokum karena kesalahannya, maka Notaris tersebut dapat dituntut untuk mengganti biaya, ganti rugi dan bunga oleh para penghadap yang mengalami kerugian tersebut.

\section{Tanggung jawab Notaris dalam menjalankan tugas jabatannya berdasarkan kode etik Notaris}

Tanggung jawab Notaris berdasarkan kode etik Notaris ini merupakan merupakan konsekuensi logis dari untuk suatu pekerjaan yang disebut profesi. Kode Etik Notaris ini ada untuk menjaga perilaku dan profesionalitas seorang Notaris dalam melaksanakan jabatannya dalam melayani masyarakat dan apabila seorang Notaris melanggar ketentuan yang ada di dalam Kode Etik 
Eric Sandro \& Tjempaka

EFEKTIVITAS MENGENAI KEPASTIAN HUKUM PENERAPAN DELIK FORMIL DALAM PASAL 2 AYAT (1) JUNCTO PASAL 3

\section{Jurnal Huknem Adigamâ}

Volume 2 Nomor 2, Desember 2019 E-ISSN: 2655-7347 UNDANG-UNDANG NOMOR 20 TAHUN 2001 TENTANG PERUBAHAN ATAS

UNDANG-UNDANG NOMOR 31 TAHUN 1999 TENTANG PEMBERANTASAN TINDAK PIDANA KORUPSI (STUDI PUTUSAN MAHKAMAH KONSTITUSI REPUBLIK INDONESIA NOMOR 25/PUU-XIV/2016)

Notaris tersebut maka tentu saja akan mendapatkan sanksi-sanksi dari anggota perkumpulan Notaris.

\section{B. Tanggung jawab Notaris terhadap Akta Autentik yang dibuatnya dengan} Surat Kuasa yang cacat hukum

Di dalam kasus yang diteliti di penelitian ini terdapat sebuah permasalahan dalam penandatanganan akta yang dimana kronologinya adalah Penggugat dalam menandatangani akta hanya dilakukan bersama dengan Tergugat II saja tidak bersama dengan Tergugat I. Tidak hadirnya Tergugat I mengakibatkan Penggugat tidak mengetahui bahwa pada saat perwakilan/penerima kuasa dari Tergugat I menandatangani akta sewa menyewa tersebut, perwakilan/penerima kuasa dari Tergugat I tersebut tidak memiliki surat kuasa dari Tergugat I. Namun Tergugat II tetap melakukan proses penandatanganan akta dan menulis komparisi dari Tergugat I sebagai penghadap dalam kedudukannya berdasarkan surat kuasa. Hal tersebut baru diketahui oleh Penggugat dua minggu setelah akta sewa menyewa tersebut ditandatangani saat Penggugat meminta salinan akta kepada Tergugat II dan Tergugat II memberitahu kepada Penggugat bahwa surat kuasa milik Tergugat I belum turun dari kantor pusat Tergugat I dan belum diterima oleh Tergugat II. Hal ini, menunjukkan tidak adanya itikad baik dari Tergugat I dan Tergugat II kepada Penggugat karena apabila Penggugat tidak pernah menanyakan maka Tergugat I dan Tergugat II tidak akan mengatakan kepada Penggugat surat kuasa dari Tergugat I tidak ada.

Menurut Bapak Boy Nurdin, Padahal seorang Notaris dalam melaksanakan penandatangan suatu akta autentik para penghadap juga harus dipertemukan jika salah satu penghadapnya merupakan perwakilan yang menerima kuasa dan di dalam kasus ini Notaris juga tidak mempertemukan penghadap dengan perwakilan dari penghadap lainnya dan menurut beliau hal ini telah merupakan sebuah pelanggaran dan seharusnya Notaris juga tidak menunjukkan keberpihakan dalam sebuah penandatanganan akta, yang dimana apabila salah 
Eric Sandro \& Tjempaka

EFEKTIVITAS MENGENAI KEPASTIAN HUKUM PENERAPAN DELIK FORMIL DALAM PASAL 2 AYAT (1) JUNCTO PASAL 3

\section{Jurnal Huknen Adigamä}

Volume 2 Nomor 2, Desember 2019 E-ISSN: 2655-7347
UNDANG-UNDANG NOMOR 20 TAHUN 2001 TENTANG PERUBAHAN ATAS UNDANG-UNDANG NOMOR 31 TAHUN 1999 TENTANG PEMBERANTASAN TINDAK PIDANA KORUPSI (STUDI PUTUSAN MAHKAMAH KONSTITUSI REPUBLIK INDONESIA NOMOR 25/PUU-XIV/2016)

satu penghadap yang mewakilkan kuasanya dalam menandatangani akta tidak memiliki surat kuasa, seharusnya Notaris yang bersangkutan memberitahu kepada penghadap lainnya. ${ }^{8}$

Dalam menjalankan jabatannya untuk membuat akta autentik, seorang Notaris memiliki sebuah kewajiban untuk menjalankan tugasnya berdasarkan peraturan-peraturan yang terdapat di dalam UUJN. Notaris dalam melaksanakan jabatannya juga diwajibkan untuk bertindak secara saksama, jujur, tidak berpihak, mandiri dan menjaga kepentingan para penghadap yang dating ke Notaris untuk membuat sebuah perbuatan hukum, sebagaimana diatur di dalam Pasal 16 UUJN-P.

Pada dasarnya akta autentik yang dibuat oleh seorang Notaris adalah sebuah perjanjian yang dibuat oleh para penghadap dihadapan seorang Notaris dan perjanjian tersebut dituliskan ke dalam suatu akta autentik yang memiliki kekuatan pembuktian yang sempurna. Oleh karena itu, perjanjian yang dibuat oleh para penghadap ini juga harus sesuai dengan syarat-syarat sahnya sebuah perjanjian yang telah di atur di dalam Pasal 1320 KUHPerdata. Syarat sahnya sebuah perjanjian juga terbagi menjadi dua bagian yaitu syarat subjektif yaitu syarat mengenai subjek yang melakukan perbuatan hokum dalam hal ini perjanjian, yang terdiri dari kata sepakat dan cakap bertindak untuk melakukan suatu perbuatan hukum. ${ }^{9)}$

Apabila syarat subjektif dari syarat sahnya perjanjian tidak terpenuhi, maka perjanjian tersebut dapat dimintakan pembatalannya ke pengadilan (vernietigbaar) sepanjang ada permintaan oleh orang-orang tertentu atau yang berkepentingan. ${ }^{10)}$ Apabila Penggugat maupun Tergugat I megajukan permintaan pembatalan perjanjian sewa menyewa tersebut kepada pengadilan,

8) Peneliti, Wawancara, dengan Dr. Boy Nurdin., S.H., M.H., (Jakarta: Universitas Tarumanagara, 11 November 2019).

9) Habib Adjie, Kebatalan dan Pembatalan Akta Notaris, (Bandung: Refika Aditama, 2015), hal.68.

10) Ibid., hal.65. 
Eric Sandro \& Tjempaka

EFEKTIVITAS MENGENAI KEPASTIAN HUKUM PENERAPAN DELIK FORMIL DALAM PASAL 2 AYAT (1) JUNCTO PASAL 3

maka perjanjian sewa menyewa tersebut dapat dibatalkan yang tentunya menyebabkan kerugian bagi para pihak baik Penggugat maupun Tergugat I.

Kerugian yang timbul akibat dari pembatalan perjanjian sewa menyewa tersebut menjadi tanggung jawab dari Tergugat II selaku Notaris yang membuat akta sewa menyewa tersebut. Hal ini dikarenakan Tergugat II pada saat penandatanganan akta sewa menyewa seharusnya memastikan bahwa perwakilan dari Tergugat I telah memiliki surat kuasa dari kantor Tergugat I untuk memastikan perwakilan dari Tergugat I memiliki kewenangan untuk menandatangani akta sewa menyewa tersebut.

Namun Tergugat II tidak melakukan hal tersebut, dan ini menunjukkan bahwa Tergugat II dalam menjalankan jabatannya tidak bertindak secara cermat dan saksama sebagaimana diatur didalam Pasal 16 UUJN-P, dan Tergugat II mempersilahkan perwakilan dari Tergugat I untuk menandatangani akta walaupun perwakilan dari Tergugat I tidak memiliki surat kuasa. Hal ini tentu saja bertentangan dengan undang-undang karena Tergugat II dalam membuat akta dan melaksananakan penandatanganan akta sewa menyewa tersebut dengan perwakilan dari Tergugat I yang tidak memiliki kewenangan dan menyatakan bahwa penghadap tersebut memiliki kewenangan berdasarkan kuasa yang tidak ia miliki saat itu.

Tergugat II juga seharusnya melekatkan surat kuasa autentik ataupun surat kuasa di bawah tangan yang menjadi dasar kewenangan pembuatan akta di dalam minuta akta pada saat pendantangan akta sewa menyewa tersebut sebagaimana diatur di dalam Pasal 47 ayat (1) UUJN. Walaupun kuasa dapat diberikan kepada penerima kuasa dilakukan secara lisan. Namun dalam melakukan perbuatan hukum dihadapan seorang notaris, seharusnya Tergugat II meminta bukti pemberian kuasa yaitu berupa surat kuasa. Hal ini dikarenakan dalam membuktikan pemberian kuasa lisan adalah sangat sulit, oleh karena itu pemberian lisan sebaiknya dilakukan secara tertulis untuk memastikan bahwa perwakilan dari Tergugat I benar-benar memiliki kewenangan atau kecakapan dalam mewakili Tergugat I untuk menandatangani akta sewa menyewa tersebut. 
Eric Sandro \& Tjempaka

EFEKTIVITAS MENGENAI KEPASTIAN HUKUM PENERAPAN DELIK FORMIL DALAM PASAL 2 AYAT (1) JUNCTO PASAL 3

\section{Jurnal Huknem Adigamä}

Volume 2 Nomor 2, Desember 2019 E-ISSN: 2655-7347 UNDANG-UNDANG NOMOR 20 TAHUN 2001 TENTANG PERUBAHAN ATAS UNDANG-UNDANG NOMOR 31 TAHUN 1999 TENTANG PEMBERANTASAN TINDAK PIDANA KORUPSI (STUDI PUTUSAN MAHKAMAH KONSTITUSI REPUBLIK INDONESIA NOMOR 25/PUU-XIV/2016)

Menurut Bapak Risbert, Apabila dalam penandatanganan suatu akta autentik ternyata Notaris tidak melekatkan dokumen-dokumen yang diperlukan didalam minuta akta seperti Surat Kuasa, hal ini berarti Notaris yang bersangkutan telah melakukan pelanggaran terhadap UUJN dan Kode Etik karena Surat Kuasa merupakan bagian dari Komparisi yang terdapat pada kepala akta yang isinya merupakan tanggung jawab dari Notaris berbeda dengan isi akta autentik yang sepenuhnya ditentukan oleh para penghadap. Notaris seharusnya lebih berhati-hati dalam menulis komparisi dari para penghadap terutama apabila salah satu penghadap merupakan Perseoran Terbatas (PT) yang seringkali dalam penandatanganan suatu akta mewakilkan kuasanya. $^{11)}$

Menurut Penulis kelalaian yang dilakukan oleh Tergugat II merupakan suatu perbuatan melawan hukum karena mengakibatkan kerugian kepada para penghadap yang membuat perjanjian sewa menyewa tersebut sebagaimana dimaksud dalam pasal 1365 KUHPerdata:

"Tiap perbuatan melawan hukum yang oleh karenanya menimbulkan kerugian pada orang lain, mewajibkan orang yang karena kesalahannya menyebabkan kerugian itu mengganti kerugian"

Padahal Notaris dalam menjalankan jabatannya harus cermat, teliti dan berhati-hati, semua dokumen yang dibutuhkan dalam proses penandatanganan minuta akta seharusnya sudah lengkap dan diketahui oleh para pihak.

Jika dokumen yang diperlukan tersebut belum lengkap sebaiknya Notaris memberitahukan kepada para pihak agar dokumen tersebut segera diberikan kepada Notaris, agar tidak dianggap seakan-akan Notaris berpihak kepada salah satu pihak.

Berkaitan dengan kasus dalam penelitian ini, penulis berpendapat sanksi yang harus dikenakan terhadap Notaris dalam kasus ini adalah

\footnotetext{
11) Peneliti, Wawancara, dengan Risbert., S.H., M.H., (Jakarta: Universitas Tarumanagara, 1 November 2019).
} 
Eric Sandro \& Tjempaka

EFEKTIVITAS MENGENAI KEPASTIAN HUKUM PENERAPAN DELIK FORMIL DALAM PASAL 2 AYAT (1) JUNCTO PASAL 3 UNDANG-UNDANG NOMOR 20 TAHUN 2001 TENTANG PERUBAHAN ATAS UNDANG-UNDANG NOMOR 31 TAHUN 1999 TENTANG PEMBERANTASAN TINDAK PIDANA KORUPSI (STUDI PUTUSAN MAHKAMAH KONSTITUSI REPUBLIK INDONESIA

Volume 2 Nomor 2, Desember 2019 E-ISSN: 2655-7347

1. Sanksi perdata.

Sanksi perdata yang dapat diterima oleh seorang Notaris telah diatur di dalam Pasal 84 UUJN yang di mana sebelumnya juga pernah diatur di dalam Pasal 60 PJN (Peraturan Jabatan Notaris). Terdapat syarat-syarat agar seorang Notaris dapat dituntut secara perdata yang dimana adalah sebagai berikut:

a. Apabila hal-hal yang secara tegas ditentukan oleh PJN telah terpenuhi;

b. Apabila sebuah akta autentik yang dibuat oleh Notaris tidak memenuhi syarat-syarat yang telah ditentukan mengenai bentuk (gebrek in de vorm) karena kesalahan Notaris, dibatalkannya akta autentik yang dibuat oleh Notaris di muka pengadilan atau mengalami degradasi dan hanya memiliki status sebagai sebuah akta yang dibuat di bawah tangan;

c. Dalam hal dimana menurut ketentuan-ketentuan dalam Pasal 1365, Pasal 1366 dan Pasal 1367 KUHPerdata terdapat kewajiban untuk membayar ganti kerugian. ${ }^{12)}$

Dengan dilanggarnya syarat subjektif dalam syarat sahnya suatu perjanjian, maka status akta autentik tersebut berubah menjadi akta dibawah tangan dan kekuatan pembuktian maupun keberadaan akta tersebut menjadi lebih lemah sehingga menyebabkan kerugian kepada para penghadap. Oleh karena itu, Notaris di dalam kasus ini haruslah bertanggung jawab secara perdata dan membayar semua kerugian yang timbul. Dan para penghadap juga dapat menggugat Notaris atas dasar perbuatan melawan hokum (PMH) karena dikarenakan kesalahan yang dilakukan oleh Notaris tersebut para penghadap mengalami kerugian. Dan menurut Bapak Gunawan, untuk membuktikan kesalahan seorang Notaris yang menyebabkan kerugian terhadap para penghadap adalah dengan cara menggugat Notaris tersebut di Pengadilan atas dasar Perbuatan Melawan Hukum (PMH) dan kemudian kesalahan-kesalahan Notaris tersebut dibuktikan di Pengadilan dalam tahap pembuktian dengan mengajukan bukti-bukti. ${ }^{13)}$

12) Habib Adjie, Sanksi Perdata Dan Administratif Terhadap Notaris Sebagai Pejabat Publik, (Bandung: Refika Aditama, 2008), hal.104.

${ }^{13)}$ Peneliti, Wawancara, dengan Dr.Gunawan Djajaputra S.H., M.H., C.N. (Jakarta: Universitas Tarumanagara, 28 Oktober 2019). 
Eric Sandro \& Tjempaka

EFEKTIVITAS MENGENAI KEPASTIAN HUKUM PENERAPAN DELIK FORMIL DALAM PASAL 2 AYAT (1) JUNCTO PASAL 3

\section{Jurnal Huknem Adigamâ}

Volume 2 Nomor 2, Desember 2019 E-ISSN: 2655-7347 UNDANG-UNDANG NOMOR 20 TAHUN 2001 TENTANG PERUBAHAN ATAS UNDANG-UNDANG NOMOR 31 TAHUN 1999 TENTANG PEMBERANTASAN TINDAK PIDANA KORUPSI (STUDI PUTUSAN MAHKAMAH KONSTITUSI REPUBLIK INDONESIA NOMOR 25/PUU-XIV/2016)

\section{Sanksi Administratif}

Selain sanksi perdata diatas, para penghadap juga dapat mengajukan laporan mengenai pelanggaran yang dilakukan oleh Notaris kepada MPD (Majelis Pengawas Daerah) untuk pelanggaran UUJN maupun (Dewan Kehormatan Daerah) untuk pelanggaran Kode Etik Notaris, dan untuk pelanggaran UUJN kemudian pihak MPD akan melakukan pemanggilan terhadap Notaris yang bersangkutan dan para penghadap untuk dilakukan mediasi diantara mereka, apabila mediasi tidak berhasil dan Notaris terbukti melakukan kesalahan dalam menjalankan jabatannya, maka kemudian MPD akan memberikan usulan kepada MPW (Majelis Pengawas Daerah), dan oleh MPW kemudian akan mempelajari dan mendalami usulan yang diberikan oleh MPD tersebut.

Dalam mempelajari dan mendalami usulan MPD tersebut, MPW akan kembali memanggil Notaris yang bersangkutan untuk diperiksa dan apabila oleh MPW ditemukan pelanggaran, MPW kemudian akan memberikan usulan kepada MPP (Majelis Pengawas Daerah) karena MPW tidak mempunyai kewenangan dalam menjatuhkan putusan berupa sanksi terhadap Notaris yang bersangkutan.

Lalu kemudian oleh MPP akan dilakukan lagi pemeriksaan terhadap Notaris atas usulan MPW tersebut. Apabila benar Notaris yang bersangkutan ditemukan bersalah, MPP dapat memberikan sanksi berupa sanksi teguran hingga pemberhentian Notaris yang terbukti melakukan kesalahan tersebut. Putusan oleh MPP tersebut kemudian akan diproses oleh Kementerian Hukum dan Hak Asasi Manusia Republik Indonesia.

Untuk pelanggaran Kode Etik Notaris, setelah ada pelaporan ataupun dugaan seorang Notaris telah melakukan pelanggaran kode etik, maka 
Eric Sandro \& Tjempaka

EFEKTIVITAS MENGENAI KEPASTIAN HUKUM PENERAPAN DELIK FORMIL DALAM PASAL 2 AYAT (1) JUNCTO PASAL 3

\section{Jurnal Huknem Adigamâ}

Volume 2 Nomor 2, Desember 2019 E-ISSN: 2655-7347
UNDANG-UNDANG NOMOR 20 TAHUN 2001 TENTANG PERUBAHAN ATAS UNDANG-UNDANG NOMOR 31 TAHUN 1999 TENTANG PEMBERANTASAN TINDAK PIDANA KORUPSI (STUDI PUTUSAN MAHKAMAH KONSTITUSI REPUBLIK INDONESIA NOMOR 25/PUU-XIV/2016)

kemudian DKD akan mengadakan sidang untuk membicarakan mengenai laporan atau dugaan pelanggaran tersebut. Apabila di dalam sidang DKD tersebut ternyata ada dugaan yang kuat mengenai pelanggaran kode etik, Notaris yang bersangkutan akan dipanggil dan diberikan kesempatan untuk membela diri, kemudian DKD akan melakukan sidang untuk memeriksa mengenai pelanggaran tersebut, dan apabila Notaris terbukti melakukan pelanggaran maka DKD akan menjatuhkan sanksi kepada Notaris tersebut. Untuk sanksi pemberhentian sementara dari anggota perkumpulan dan pemecatan dari anggota perkumpulan, DKD wajib berkonsultasi terlebih dahulu dengan Pengurus Daerahnya.

Putusan DKD yang berisi pemberhentian sementara dan pemecatan dapat diajukan banding kepada Dewan Kehormatan Wilayah (DKW) untuk mendapatkan putusan banding, dan putusan banding DKW tersebut dapat diajukan lagi kepada Dewan Kehormatan Pusat (DKP) untuk mendapatkan putusan akhir. Pengenaan sanksi pemberhentian sementara atau pemecatan ini wajib diberitahukan kepada Pengurus Pusat, MPD dan Kemenkumham RI

\section{B. Tanggung jawab Notaris terhadap Akta Autentik yang tidak dibacakan dihadapan para pihak.}

Seorang Notaris dalam melaksanakan jabatannya sebagai seorang pejabat umum haruslah bekerja dengan benar dan profesional agar Notaris mampu membuat sebuah akta autentik dalam bentuk yang benar dan sempurna untuk para penghadap yang telah datang untuk menggunakan jasa seorang Notaris. Sebagaimana ditentukan oleh UUJN, Notaris memiliki sebuah kewenangan untuk membuat suatu akta autentik yang memiliki kekuatan pembuktian yang sempurna yang berisikan perbuatan-perbuatan hukum, perjanjian dan kebutuhan para pihak yang datang ke hadapan Notaris. 
Eric Sandro \& Tjempaka

EFEKTIVITAS MENGENAI KEPASTIAN HUKUM PENERAPAN DELIK FORMIL DALAM PASAL 2 AYAT (1) JUNCTO PASAL 3

\section{Jurnal Huknem Adigamâ}

Volume 2 Nomor 2, Desember 2019 E-ISSN: 2655-7347 UNDANG-UNDANG NOMOR 20 TAHUN 2001 TENTANG PERUBAHAN ATAS UNDANG-UNDANG NOMOR 31 TAHUN 1999 TENTANG PEMBERANTASAN TINDAK PIDANA KORUPSI (STUDI PUTUSAN MAHKAMAH KONSTITUSI REPUBLIK INDONESIA NOMOR 25/PUU-XIV/2016)

Menurut Bapak Risbert persyaratan sebuah akta autentik diatur dialam Pasal 1868 KUHPerdata yang dimana sebuah akta autentik harus dibuat dihadapan seorang pejabat umum yang berwenang atau seorang Notaris di dalam bentuk akta autentik yang telah ditetapkan oleh Undang-undang, pengaturan mengenai bentuk akta autentik yang dibuat oleh seorang Notaris dapat ditemukan di dalam UUJN dan dalam pembuatan akta autentik tersebut harus dilakukan secara Verlijden yang dimana maksud dari Verlijden adalah serangkaian tindakan-tindakan yang merupakan sebuah keharusan untuk dilakukan oleh seorang Notaris, saksi-saksi dan para penghadap yang di mana prosesnya dimulai dengan pembuatan suatu akta autentik oleh Notaris yang kemudian akta yang telah dibuat tersebut dibacakan oleh notaris kepada para penghadap dan saksi-saksi agar para penghadap mengerti dan mengetahui isi dari akta tersebut dan akhirnya akta autentik tersebut ditandatangani oleh para penghadap, saksi-saksi dan Notaris. ${ }^{14)}$

Hal tersebut diatur lebih lanjut di dalam Pasal 16 ayat (1) huruf m UUJN$\mathrm{P}$, yang menyatakan bahwa seorang Notaris harus membacakan isi dari akta autentik yang dibuat olehnya sebelum dilaksanakan penandatanganan akta oleh para penghadap yang juga harus dihadiri dan disaksikan oleh setidaknya dua orang saksi, hal ini dilakukan agar para penghadap memahami isi akta dan tidak terjadi kesalahpahaman mengenai isi akta tersebut. Namun akta autentik tidak perlu dibacakan oleh Notaris kepada para penghadap dengan syarat bahwa para penghadap telah membaca sendiri mengenai isi akta dan memahami isi akta tersebut.

Pembacaan akta ini wajib dilakukan oleh Notaris dihadapan para penghadap, dan menurut Pasal 28 PJN disebutkan bahwa setiap akta autentik yang dibuat oleh seorang Notaris sebelum ditandatangani oleh para pihak,

14) Peneliti, Wawancara, dengan Risbert., S.H., M.H., (Jakarta: Universitas Tarumanagara, 1 November 2019). 
Eric Sandro \& Tjempaka

EFEKTIVITAS MENGENAI KEPASTIAN HUKUM PENERAPAN DELIK FORMIL DALAM PASAL 2 AYAT (1) JUNCTO PASAL 3

\section{Jurnal Huknum Adigamä}

Volume 2 Nomor 2, Desember 2019 E-ISSN: 2655-7347
UNDANG-UNDANG NOMOR 20 TAHUN 2001 TENTANG PERUBAHAN ATAS UNDANG-UNDANG NOMOR 31 TAHUN 1999 TENTANG PEMBERANTASAN TINDAK PIDANA KORUPSI (STUDI PUTUSAN MAHKAMAH KONSTITUSI REPUBLIK INDONESIA NOMOR 25/PUU-XIV/2016)

haruslah dibacakan oleh Notaris kepada para penghadap dan para saksi, pembacaan akta ini dilakukan terhadap akta partai maupun akta pejabat. Pembacaan akta dihadapan para penghadap ini disebut dengan verlijden (pembacaan dan penandantangan) akta.

Di dalam kasus penelitian ini, Tergugat II selaku Notaris pada saat penandatanganan akta autentik tidak membacakan akta tersebut kepada Penggugat hal ini dikarenakan pada saat penandatanganan akta tersebut, perwakilan dari Tergugat I tidak hadir dan juga tidak memiliki surat kuasa dari kantor Tergugat I namun Tergugat II tetap meminta Penggugat untuk menandatangani akta tersebut. Tergugat II juga tergesa-gesa menyuruh Penggugat untuk segera menandatangani akta autentik tersebut yang menunjukkan bahwa Tergugat II seolah-olah memihak kepada Tergugat I karena perwakilan Tergugat I juga tidak hadir pada saat penandatangan dan dokumen-dokumen yang harus dilekatkan ke minuta akta dari Tergugat I juga belum lengkap.

Setelah menandatangani akta tersebut Penggugat juga tidak diberikan salinan akta autentik, hal ini dikarenakan perwakilan dari Tergugat I belum menandatangani akta tersebut dan juga Tergugat II belum melengkapi dokumen-dokumen yang harus dilekatkan dalam minuta akta, sehingga Tergugat II tidak bisa memberikan salinan akta tersebut kepada Penggugat.

Kemudian setelah dua minggu sejak penandatanganan akta tersebut, barulah Penggugat diberikan salinan akta autentik namun setelah menerima salinan akta tersebut, ternyata Penggugat menemukan terdapat hal-hal yang tidak diketahui oleh Penggugat didalam akta autentik tersebut. Ketidaktahuan tersebut tentunya disebabkan oleh Tergugat II yang tergesa-gesa ingin akta tersebut ditandatangani sehingga tidak memberitahukan kepada Penggugat bahwa sebenarnya terdapat dokumen-dokumen yang belum lengkap yang tidak 
Eric Sandro \& Tjempaka

EFEKTIVITAS MENGENAI KEPASTIAN HUKUM PENERAPAN DELIK FORMIL DALAM PASAL 2 AYAT (1) JUNCTO PASAL 3

\section{Jurnal Huknum Adigamä}

Volume 2 Nomor 2, Desember 2019 E-ISSN: 2655-7347
NG NOMOR 20 TAHUN 2001 TENTANG PERUBAHAN ATAS UNDANG-UNDANG NOMOR 31 TAHUN 1999 TENTANG PEMBERANTASAN TINDAK PIDANA KORUPSI (STUDI PUTUSAN MAHKAMAH KONSTITUSI REPUBLIK INDONESIA NOMOR 25/PUU-XIV/2016)

dilekatkan pada minuta akta, dan juga tidak dibacakannya akta tersebut dihadapan Penggugat oleh Tergugat II.

Padahal Tergugat II selaku seorang pejabat umum seharusnya melaksanakan tugasnya dengan cermat, teliti dan berhati-hati. Notaris yang lalai melaksanakan kewajibannya dalam tugas jabatannya akan melahirkan sebuah akibat hukum dapat berupa sanksi administratif, perdata, maupun pidana.

Notaris yang tidak membacakan akta autentik yang dibuat olehnya kepada para penghadap sebelum penandatanganan akta berarti Notaris tersebut telah melakukan kesalahan prosedural dan Notaris tersebut juga telah melanggar peraturan dalam pembuatan suatu akta autentik. Dengan tidak dibacakannya akta autentik yang dibuat oleh Notaris tersebut pada saat penandatangan akan mengakibatkan akta autentik tersebut mengalami cacat formil dan akta autentik tersebut akan mengalami degradasi atau turunnya status akta autentik tersebut menjadi sebuah akta di bawah tangan yang kekuatan pembuktiannya tidak sempurna dan keberadaan akta tersebut dapat di sangkal dipengadilan yang berbeda dengan akta autentik yang memiliki kekuatan pembuktian yang sempurna. Degradasi atau turunnya status akta autentik yang tidak dibacakan menjadi akta di bawah tangan tersebut dapat ditemukan dalam Pasal 16 ayat (9) UUJN-P yang menyatakan:

"jika salah satu syarat sebagaimana yang dimaksud pada ayat (1) huruf m dan ayat (7) tidak dipenuhi, akta yang bersangkutan hanya mempunyai kekuatan pembuktian sebagai akta dibawah tangan."

Tergredasinya sebuah akta yang seharusnya akta autentik menjadi akta di bawah tangan tentu saja akan mengakibatkan kerugian bagi para penghadap karena akta di bawah tangan mempunyai kekuatan pembuktian yang tidak sempurna di pengadilan dan kebenaran akta di bawah tangan dapat disangkal kebenarannya oleh salah satu pihak.

Seorang Notaris harus bertanggung jawab terhadap akta autentik yang dibuat olehnya dan di dalam pembuatan akta tersebut, pembacaan akta 
Eric Sandro \& Tjempaka

EFEKTIVITAS MENGENAI KEPASTIAN HUKUM PENERAPAN DELIK FORMIL DALAM PASAL 2 AYAT (1) JUNCTO PASAL 3 UNDANG-UNDANG NOMOR 20 TAHUN 2001 TENTANG PERUBAHAN ATAS UNDANG-UNDANG NOMOR 31 TAHUN 1999 TENTANG PEMBERANTASAN TINDAK PIDANA KORUPSI (STUDI PUTUSAN MAHKAMAH KONSTITUSI REPUBLIK INDONESIA

Volume 2 Nomor 2, Desember 2019 E-ISSN: 2655-7347

merupakan suatu kewajiban yang wajib dilakukan dalam setiap pembuatan akta autentik yang merupakan bagian dari verlijden (pembacaan dan penandatanganan). Akta autentik yang dibuat oleh seorang Notaris harus dibacakan dihadapan para penghadap karena akta autentik tersebut merupakan tanggung jawab dari Notaris, sehingga apabila terjadi kesalahpahaman antara para pihak mengenai akta autentik yang dibuat tersebut tentu saja kemudian akan menyebabkan terjadinya wanprestasi oleh salah satu pihak tersebut, kesalahpahaman tersebut terjadi diakibatkan karena Notaris yang bersangkutan dengan sengaja tidak membacakan akta autentik yang dibuat olehnya sehingga mengakibatkan akta autentik yang dibuatnya tersebut menjadi batal dan mengalami penurunan status menjadi akta di bawah tangan.

Menurut pendapat penulis Notaris dalam kasus ini, telah gagal melakukan kewajibannya sebagai seorang pejabat umum yakni tidak membacakan akta di hadapan para penghadap, maka Notaris yang bersangkutan dapat dikenakan sanksi berdasarkan Pasal 84 dan 85 UUJN. Tanggung jawab seorang Notaris dalam membacakan suatu akta autentik di hadapan para penghadap adalah sangat penting, karena pembacaan akta tersebut secara langsung mempengaruhi kekuatan pembuktian akta tersebut, yang apabila terdapat kesalahan maka akan memberikan kerugian kepada para penghadap.

Oleh karena itu penulis berpendapat Notaris yang bersangkutan seharusnya diberikan sanksi oleh pihak MPD yang dimana MPD ini berfungsi untuk mengawasi dan membina Notaris terkait dengan pelanggaran UUJN dan kode etik dan dapat menjatuhan sanksi-sanksi kepada Notaris sebagai berikut:

\section{Sanksi Administratif}

Selain sanksi perdata diatas, para penghadap juga dapat mengajukan laporan mengenai pelanggaran yang dilakukan oleh Notaris kepada MPD (Majelis Pengawas Daerah) untuk pelanggaran UUJN maupun (Dewan Kehormatan Daerah) untuk pelanggaran Kode Etik Notaris, dan untuk 
Eric Sandro \& Tjempaka

EFEKTIVITAS MENGENAI KEPASTIAN HUKUM PENERAPAN DELIK FORMIL DALAM PASAL 2 AYAT (1) JUNCTO PASAL 3

\section{Jurnal Huknum Adigamä}

Volume 2 Nomor 2, Desember 2019 E-ISSN: 2655-7347 UNDANG-UNDANG NOMOR 20 TAHUN 2001 TENTANG PERUBAHAN ATAS UNDANG-UNDANG NOMOR 31 TAHUN 1999 TENTANG PEMBERANTASAN TINDAK PIDANA KORUPSI (STUDI PUTUSAN MAHKAMAH KONSTITUSI REPUBLIK INDONESIA NOMOR 25/PUU-XIV/2016)

pelanggaran UUJN kemudian pihak MPD akan melakukan pemanggilan terhadap Notaris yang bersangkutan dan para penghadap untuk dilakukan mediasi diantara mereka, apabila mediasi tidak berhasil dan Notaris terbukti melakukan kesalahan dalam menjalankan jabatannya, maka kemudian MPD akan memberikan usulan kepada MPW (Majelis Pengawas Daerah), dan oleh MPW kemudian akan mempelajari dan mendalami usulan yang diberikan oleh MPD tersebut.

Dalam mempelajari dan mendalami usulan MPD tersebut, MPW akan kembali memanggil Notaris yang bersangkutan untuk diperiksa dan apabila oleh MPW ditemukan pelanggaran, MPW kemudian akan memberikan usulan kepada MPP (Majelis Pengawas Daerah) karena MPW tidak mempunyai kewenangan dalam menjatuhkan putusan berupa sanksi terhadap Notaris yang bersangkutan.

Lalu kemudian oleh MPP akan dilakukan lagi pemeriksaan terhadap Notaris atas usulan MPW tersebut. Apabila benar Notaris yang bersangkutan ditemukan bersalah, MPP dapat memberikan sanksi berupa sanksi teguran hingga pemberhentian Notaris yang terbukti melakukan kesalahan tersebut. Putusan oleh MPP tersebut kemudian akan diproses oleh Kementerian Hukum dan Hak Asasi Manusia Republik Indonesia.

Untuk pelanggaran Kode Etik Notaris, setelah ada pelaporan ataupun dugaan seorang Notaris telah melakukan pelanggaran kode etik, maka kemudian DKD akan mengadakan sidang untuk membicarakan mengenai laporan atau dugaan pelanggaran tersebut. Apabila di dalam sidang DKD tersebut ternyata ada dugaan yang kuat mengenai pelanggaran kode etik, Notaris yang bersangkutan akan dipanggil dan diberikan kesempatan untuk membela diri, kemudian DKD akan melakukan sidang untuk memeriksa mengenai pelanggaran tersebut, dan apabila Notaris terbukti melakukan pelanggaran maka DKD akan menjatuhkan sanksi kepada Notaris tersebut. 
Eric Sandro \& Tjempaka

EFEKTIVITAS MENGENAI KEPASTIAN HUKUM PENERAPAN DELIK FORMIL DALAM PASAL 2 AYAT (1) JUNCTO PASAL 3

\section{Jurnal Huknum Adigamä}

Volume 2 Nomor 2, Desember 2019 E-ISSN: 2655-7347
UNDANG-UNDANG NOMOR 20 TAHUN 2001 TENTANG PERUBAHAN ATAS UNDANG-UNDANG NOMOR 31 TAHUN 1999 TENTANG PEMBERANTASAN TINDAK PIDANA KORUPSI (STUDI PUTUSAN MAHKAMAH KONSTITUSI REPUBLIK INDONESIA NOMOR 25/PUU-XIV/2016)

Untuk sanksi pemberhentian sementara dari anggota perkumpulan dan pemecatan dari anggota perkumpulan, DKD wajib berkonsultasi terlebih dahulu dengan Pengurus Daerahnya.

Putusan DKD yang berisi pemberhentian sementara dan pemecatan dapat diajukan banding kepada Dewan Kehormatan Wilayah (DKW) untuk mendapatkan putusan banding, dan putusan banding DKW tersebut dapat diajukan lagi kepada Dewan Kehormatan Pusat (DKP) untuk mendapatkan putusan akhir. Pengenaan sanksi pemberhentian sementara atau pemecatan ini wajib diberitahukan kepada Pengurus Pusat, MPD dan Kemenkumham RI

2. Sanksi Perdata

Menurut Penulis Notaris dalam kasus yang diteliti ini dapat dikenakan sanksi perdata yang telah diatur di dalam Pasal 84 UUJN yang di mana sebelumnya juga pernah diatur di dalam Pasal 60 PJN (Peraturan Jabatan Notaris). Dengan tidak dibacakannya akta autentik tersebut pada saat penandatangan menyebabkan akta autentik tersebut mengalami degradasi akta tersebut menjadi sebuah akta di bawah tangan yang tentu saja akan mengakibatkan kerugian bagi para penghadap tersebut. Notaris yang telah mengakibatkan kerugian kepada para penghadap tersebut haruslah mengganti kerugian yang timbul dan para penghadap yang mengalami kerugian tersebut juga dapat menggugat secara perdata di pengadilan karena perbuatan melawan hokum yang dilakukan oleh Notaris tersebut.

\section{Penutup}

\section{A. Kesimpulan}

Berdasarkan permasalahan yang telah diuraikan tersebut diatas dan analisis data yang diperoleh dari hasil penelitian maka dapat disimpulkan bahwa:

1. Apabila salah satu penghadap merupakan perwakilan dalam menandatangani akta autentik seharusnya Notaris memastikan perwakilan 
Eric Sandro \& Tjempaka

EFEKTIVITAS MENGENAI KEPASTIAN HUKUM PENERAPAN DELIK FORMIL DALAM PASAL 2 AYAT (1) JUNCTO PASAL 3

Jurnal Huknem Adigamâ

Volume 2 Nomor 2, Desember 2019 E-ISSN: 2655-7347 UNDANG-UNDANG NOMOR 20 TAHUN 2001 TENTANG PERUBAHAN ATAS UNDANG-UNDANG NOMOR 31 TAHUN 1999 TENTANG PEMBERANTASAN TINDAK PIDANA KORUPSI (STUDI PUTUSAN MAHKAMAH KONSTITUSI REPUBLIK INDONESIA NOMOR 25/PUU-XIV/2016)

tersebut mempunyai surat kuasa dan melekatkannya di minuta akta, apabila perwakilan tersebut tidak memiliki surat kuasa tentu saja menyebabkan sebuah permasalahan mengenai kecakapannya, hal ini dikarenakan penerima kuasa dari surat kuasa yang cacat hukum tidak memiliki kecakapan atau kewenangan dalam mewakili sebuah perseoran terbatas untuk melakukan perbuatan hukum. Dikarenakan tidak cakapnya penerima kuasa dalam menandatangani suatu perjanjian mengakibatkan syarat subyektif suatu perjanjian tidak terpenuhi sehingga perjanjian tersebut menjadi dapat dibatalkan demi hukum dan salah satu pihak dapat memintakan pembatalannya ke pengadilan. Pembatalan perjanjian tersebut dapat mengakibatkan kerugian kepada salah satu pihak dan Notaris yang membuat akta autentik tersebutlah bertanggung jawab atas kerugian yang timbul dikarenakan ketidaktelitian dan tidak berhati-hati dalam membuat suatu akta autentik.

2. Akibat dari tidak dibacakannya suatu akta autentik ketika akan ditandatangani adalah hilangnya kekuatan pembuktian absolut sebuah akta autentik menjadi sebuah akta dibawah tangan yang kekuatan pembuktiannya menjadi tidak sempurna karena dapat disangkal oleh salah satu pihak, hilangnya status akta autentik dan kekuatan pembuktian sempurna ini tentu saja mengakibatkan kerugian bagi salah satu pihak karena akta dibawah tangan tersebut dapat disangkal oleh pihak lain. Oleh karena itu seorang Notaris haruslah bertanggung jawab atas kesalahan tidak membacakan akta autentik dihadapan para pihak baik secara perdata maupun administratif yang dilaksanakan oleh Majelis Pengawas Notaris dengan memberikan sanksi-sanksi administraf

\section{B. Saran}

Berdasarkan kesimpulan yang diuraikan diatas, maka dapat diberikan saran sebagai berikut: 
Eric Sandro \& Tjempaka

EFEKTIVITAS MENGENAI KEPASTIAN HUKUM PENERAPAN DELIK FORMIL DALAM PASAL 2 AYAT (1) JUNCTO PASAL 3

\section{Jurnal Huknem Adigamä}

Volume 2 Nomor 2, Desember 2019 E-ISSN: 2655-7347
UNDANG-UNDANG NOMOR 20 TAHUN 2001 TENTANG PERUBAHAN ATAS UNDANG-UNDANG NOMOR 31 TAHUN 1999 TENTANG PEMBERANTASAN TINDAK PIDANA KORUPSI (STUDI PUTUSAN MAHKAMAH KONSTITUSI REPUBLIK INDONESIA NOMOR 25/PUU-XIV/2016)

1. Seorang Notaris dalam membuat sebuah akta autentik harus cermat, teliti dan berhati-hati, terutama dalam memeriksa kecakapan dan kewenangan dari para pihak yang menggunakan surat kuasa sebagai dasar kewenangannya, notaris harus memastikan penghadap yang menghadap berdasarkan kuasa memiliki bukti atas pemberian kuasa yang kuat seperti dengan membawa surat kuasa. Apabila salah satu penghadap tidak memiliki surat kuasa seharusnya Notaris memberitahukan kepada para penghadap dan meminta untuk melengkapi dokumen-dokumen yang perlu dilekatkan diminuta akta agar tidak dianggap memihak kepada salah satu pihak.

2. Notaris sebagai seorang pejabat umum tentu saja memikul petanggungjawaban yang amat besar dalam menjalankan jabatannya. Oleh karena itu harusnya seorang Notaris menaati peraturan-peraturan yang ada, berkaitan dengan kasus ini adalah dengan membacakan akta autentik. Pembcaan sebuah akta tidak semata-mata untuk mengikuti peraturan yang ada namun pembacaan tersebut harus dilakukan agar para pihak memahami secara jelas mengenai isi akta autentik tersebut. Seorang Notaris juga harus berhati-hati dan cermat dalam melakukan tugasnya agar tidak menyebabkan kerugian yang dikarenakan kesalahannya kepada para pihak.

\section{IV.Daftar Pustaka}

\section{A. Buku}

Adjie, Habib. Kebatalan dan Pembatalan Akta Notaris. (Bandung: Refika Aditama, 2015)

Sanksi Perdata Dan Administratif Terhadap Notaris Sebagai Pejabat Publik. (Bandung: Refika Aditama, 2008)

Ghofur Anshori, Abdul. Lembaga Kenotariatan Indonesia. (Yogyakarta: UII Press, 2009)

Harahap, Yahya. Segi-Segi Hukum Perjanjian. (Bandung: Alumni, 1986)

Pasek Diantha, I Made. Metodologi Penelitian. Hukum Normatif Dalam Justifikasi Teori Hukum. (Jakarta: PT Fajar Interpratama Mandiri, 2017) 


\section{B. Artikel Jurnal}

Crystal Yoanna, Winanto Wiryomartani, dan Widodo Suryandono. "Pembuatan Akta Sewa Menyewa Atas Dasar Surat Kuasa Dan Renvoi Yang Cacat Hukum”. Notary UI. Vol.1 No.002, (2019)

Putra Arafaid, "Tanggung Jawab Hukum Notaris Terhadap Akta In Originali”. Jurnal IUS Kajian Hukum dan Keadlian, Vol.5, No.3 (2017)

\section{Wawancara}

Peneliti. Wawancara, dengan Dr. Boy Nurdin., S.H., M.H., (Jakarta: Universitas Tarumanagara, 11 November 2019)

Peneliti. Wawancara, dengan Risbert., S.H., M.H., (Jakarta: Universitas Tarumanagara, 1 November 2019)

Peneliti. Wawancara, dengan Dr. Gunawan Djajaputra S.H., M.H., C.N. (Jakarta: Universitas Tarumanagara, 28 Oktober 2019)

\section{Majalah}

Herlien Budiono. Perwakilan, Kuasa dan Pemberian Kuasa, Majalah Renvoi, Volume 4, Nomor 6.42, (November 2006) 